\title{
Improved Understanding of Intra Uterine Device and Implant Family Planning Acceptors in Family Planning Services at Solo Peduli Clinic
}

\author{
Uki Retno Budihastuti,1,2), Abdurahman Laqif(,2), Eriana Melinawati,2), Teguh \\ Prakosa, $^{1,2)}$, Hermawan Udiyanto1,2), Heru Priyanto, ${ }^{1,2)}$, Darto, ${ }^{1,2)}$, Affi Angelia \\ Ratnasari, ${ }^{1,2)}$, Asih Anggraeni1,2), Dympna Prameilita Prisasanti²)
}

1)Department of Obstetrics and Gynecology, Dr. Moewardi Hospital, Surakarta 2) Faculty of Medicine, Universitas Sebelas Maret

ABSTRACT

\begin{abstract}
Background: Family planning acceptor's understanding of intra uterine device (IUD) and implant contraception is still low, due to the lack of knowledge and negative perceptions about IUD and implants contraception in the society. Therefore, it needs an effort to increase the understanding of family planning acceptors to reduce fertility rates through increasing the use of contraception. This study aimed to analyze understanding and satisfaction of family planning acceptors with the satisfaction aspects of counseling, the comfortable effect on the insertion of contraceptives, and the satisfaction of family planning services at the Solo Peduli Clinic.

Subjects and Method: A cross sectional study was conducted at Solo Peduli Clinic, Surakarta, Central Java, from June to August 2020. A sample of 60 women divided into 2 groups: (1) 30 women who have used IUD and implant contraceptives, and (2) 30 women that will be given counselling and insertions of IUD and implant contraceptives. The study subject was selected by fixed disease sampling. The dependent variable was satisfaction. The independent variables were counselling, comfortable effect, and family planning service.
\end{abstract}

The data were collected by questionnaire and analyzed by a multiple logistic regression run on SPSS ver. 25.

Results: The average level of satisfaction of counseling, the comfortable effect of using contraceptives, and satisfaction with family planning services has an "very satisfied". Good counselling $(\mathrm{OR}=1.592 ; 95 \% \mathrm{CI}=1.097$ to 2.310; $\mathrm{p}=0.014)$, insertion convenience $(\mathrm{OR}=$ $1.428 ; 95 \% \mathrm{CI}=0.976$ to $2.090 ; \mathrm{p}=0.066)$, and good family planning service $(\mathrm{OR}=1.761$; 95\% $\mathrm{CI}=1.191$ to $2.603 ; \mathrm{p}=0.004$ ) increased satisfaction.

Conclusion: Good counselling, insertion convenience, and good family planning service increase satisfaction.

Keywords: Family planning acceptors, IUD, implants, family planning services

\section{Correspondence:}

Uki Retno Budihastuti. Department of Obstetrics and Gynecology, Dr. Moewardi Hospital/ Faculty of Medicine, Universitas Sebelas Maret, Jl. Kolonel Sutarto 132, Surakarta, Central Java. Email: ukiretno@staff.uns.ac.id. Mobile: 08122656140.

\section{Cite this as:}

Budihastuti UR, Laqif A, Melinawati E, Prakosa T, Udiyanto H, Heru Priyanto H, Darto, Ratnasari AA, Anggraeni A, Prisasanti DP (2020). Improved Understanding of Intra Uterine Device and Implant Family Planning Acceptors in Family Planning Services at Solo Peduli Clinic. J Matern Child Health. 05(04): 436445. https://doi.org/10.26911/thejmch.2020.05.04.11.

cC) (7) (2) Journal of Maternal and Child Health is licensed under a Creative Commons Attribution-NonCommercial-ShareAlike 4.o International License.

\section{BACKGROUND}

Family planning acceptor's understanding of IUD and implant is still low, due to the lack of knowledge and negative perceptions about IUD contraception and implants in the community. Therefore, it needs to increase the understanding of IUD and implants family planning acceptors in family planning services. A study needed to know whether contraceptive's counseling may give 
satisfaction to family planning acceptors. The insertion of contraceptives carried out by health workers is expected to provide a comfortable effect for family planning acceptors. The Indonesian family planning program in the Millennium Development Goals (MDGs) target requires improving maternal health in order to reduce the maternal mortality rate (MMR) from 390/ 100,000 live births in 1991 to $228 / 100,000$ live births in 2018. Fulfilling this target requires a very hard effort (Kementerian Kesehatan RI, 2015).

The study of family planning acceptors regarding counseling by doctors or medical providers needs to be done continuously. Study on whether the insertion of contraceptives provides a comfortable effect also needs to increase the number of family planning acceptors. The family planning services by health workers needs to provide satisfaction and benefit to the acceptors. These are necessary to increase the coverage of family planning acceptors in the population growth rate reduction program.

At this time, if the counseling by doctors and medical providers has not provided satisfaction of family planning acceptors, can impact the decrease of public attention to family planning programs. The use of contraceptives is very important to prevent pregnancy-related health risks for women and reduce the number of unsafe abortions (reduce infant mortality)(WHO, 2020).

Family Planning is a health service activity that aims to improve the health of mothers and children, prevent maternal and infant deaths, so that women of childbearing age can plan the number of children they want (İnal et al., 2017).Furthermore, family planning have a positive effect on women's health by reducing health problems associated with pregnancy, such as unsafe abortion (Abdulreshid and Dadi, 2020).
Long-acting reversible contraception (LARC) such as intrauterine (IUD) are one of the most effective options for preventing pregnancy, and their popularity is increasing (Hsia and Creinin, 2016; Esposito and LoGiudice, 2019) The IUD is reliable, costeffective, durable, does not affect milk production and fertility returns quickly after IUD removal. Inserting the IUD in the uterus using a simple and safe procedure (Cheung et al., 2018; Rajuddin and Fauzan, 2019). In addition, the IUD is also the most effective emergency contraception (post coitus) and reduces the risk of cervical cancer (Akintomide, 2019). However, a lack of knowledge and misunderstanding from health care providers and the public about IUDs has resulted in reduced IUD use (Kohn et al., 2012; Esposito and LoGiudice, 2019). Pregnancy rates with LARC use are lower with higher rates of continuation when compared to oral contraceptives (BulletinsGynecology, 2011).

Implanted contraception is also a longacting reversible contraception (LARC) that is convenience inexpensive, and can be used safely while breastfeeding. Implant contraception is a progesterone contraceptive that is administered subdermally (Kolawole et al., 2018; Prosad, Mashamba-Thompson and Ojewole, 2018). Implant failure rate, 1 in 100 women per year in the first 5 years (low user failure)(Everret, 2008).Barriers to use of contraceptive implants includes rejection of use by a partner or family, worry about the risks and side effects of contraception, education level, and socioeconomic status (Olmn, 2015).

The IUD contraceptive is the reversible method of contraception most commonly used by approximately $14.3 \%$ of women of reproductive age worldwide. Contraceptive IUDs are used by only $6.4 \%$ of American women using contraception (Bhatia et al., 2011). The negative effects of adolescent 
pregnancy have a high risk, namely babies born with low birth weight and preterm delivery (Women, Care and Smith, 2015). The use of the IUD has a significant public health impact by reducing the rate of unwanted pregnancies at the population level. Other benefits of using an IUD with continued insertion are cost savings, extended non-contraceptive benefits and avoiding the potential complications associated with IUD re-insertion, including pelvic inflamematory disease in the post-insertion period and the risk of uterine perforation ( $\mathrm{Wu}$ and Pickle, 2014).

Implantable birth control has a high progression rate compared to other forms of contraception and also has a very high effectiveness where the prevalence of unwanted pregnancy is less than 1 per 100 women per year (Pleaner et al., 2017). There are 2 million unwanted pregnancies that were avoided by using contraceptive implants, for more than 5 years. Therefore, short-term use of contraceptives, such as oral or injectable contraceptives, has been shifted to implant contraception (Wathoni, Alfauziah and Rantika, 2018).

The purpose of this study was to determine differences in family planning counseling satisfaction, contraceptive insertion convenience, and family planning service satisfaction on family planning acceptors who before insertion were given a detailed explanation compared to family planning acceptors who had used previous contraception. In this study, an explanation will be carried out in an effort to increase the understanding of IUD family planning acceptors and implants in family planning services in Solo Peduli clinics, then a study will be conducted on whether the explanation and counseling gives satisfaction to family planning acceptors. The insertion of contraceptives carried out by health workers did it give a comfortable effect to family planning acceptors and after the acceptors were given services, did they get satisfaction compared to family planning acceptors who were not given any education or understanding prior to inserting the IUD and implants.

\section{SUBJECTS AND METHOD \\ 1. Study Design}

This was a cross-sectional study conducted at the Clinic Solo, Surakarta, Central Java, from January 2020 to September 2020.

The authors as obstetric gynecology specialists provide counseling to improve understanding of IUD family planning acceptors and implants in family planning services at the Solo Peduli clinic. Next, a question and answer discussion was held and then the contraception was inserted according to the wishes of the family planning acceptors. Acceptors who were given counseling were distributed questionnaire covering aspects of satisfaction with counseling, the comfortable effect on the insertion of contraceptives, and satisfaction of family planning services at the Solo Peduli clinic.

\section{Population and Sample}

The study subjects were women that use IUDs and implants contraceptives at Solo Peduli clinic. The study subjects were 60 subjects divided into 2 groups. The first group of 30 subjects who have used IUD and implants, and the second group of 30 subjects who will be counseled and placed on IUD and implants.

The sample was obtained using the fixed disease sampling technique. Then the sample restrictions were carried out based on restrictions according to the inclusion and exclusion criteria that had been set. The inclusion criteria in this study are women of reproductive age that using IUD and implant contraceptives, aged 20-45 years, and there were no contra indications for IUD and 
implant birth control. The exclusion criteria in this study are women with suffering from malignancy, mental disorders, and pregnancy.

\section{Study Variables}

The dependent variable was satisfaction. The independent variables were contraceptive insertion convenience, and family planning service, and counselling.

\section{Operational Definition of Variables} Counseling satisfaction was the defined as the answer chosen by family planning acceptors regarding the satisfaction of information carried out at the time of counseling to family planning acceptors.

The comfortable effect of insertion was defined as the feeling of comfort felt by family planning acceptors regarding the contraceptive used by family planning acceptors, including its use and side effects.

Family service service satisfaction was defined as the answer chosen by family planning acceptors regarding the satisfaction of family planning services provided in Solo Peduli clinic services.

The measuring instrument used in this study was a questionnaire, with a dichotomous categorical measurement scale $(\mathrm{O}=$ not satisfied, $1=$ very satisfied).

\section{Study Instruments}

In this study, several research instruments were used to support the implementation of research, which included: 1) Questionnaires used to measure the level of satisfaction of counseling, the effect of convenient insertion, and satisfaction of family planning services by family planning acceptors, 2) Contraceptive insertion devices (IUD Set, NovaT, Implant, Implant Set).

\section{Data analysis}

Univariate tests are carried out to find the value of the distribution frequency and the percentage of respondents' answers. Furthermore, the bivariate test was carried out using Chi-square to find the significance value (p) and the odds ratio (OR) of the two research variables. Multivariate analysis was performed using multiple logistic regression.

\section{Research Ethics}

The research will be conducted after obtaining permission from the Ethics Committee of FK UNS/ RSUD Dr. Moewardi Surakarta with Number 761/VI/HREC/ 2020. Before conducting the research, the research subjects were given an explanation of the objectives and activities of this study. Research subjects who agreed and gave written informed consent were stated as respondents.

\section{RESULTS}

\section{Subject characteristics}

Family planning acceptors who were respondents in this study consisted of 60 women who participated in family planning program services at the Solo Peduli Clinic. Respondents were divided into 2 groups, namely group A consisting of 30 respondents who have used IUD and implant as control group, and group B consisting of 30 respondents who will be given counseling and the insertion of IUD and implants.

Based on the research data, it was found that the most family planning types used by family planning acceptors were implant family planning at $63.3 \%$, followed by the IUD type family planning at $36.7 \%$. The average age of family planning acceptor respondents was $\leq 36$ years $(60 \%)$. The majority of family planning acceptors last education was high school level (46.7\%), followed by junior high school (35\%), elementary school (10\%), and tertiary education (8.3\%). Most occupations of respondents are housewife $(70 \%)$, the largest number of living children is $\leq 2(61.7 \%)$, and $65 \%$ has a Body Mass Index $<25$. The complete characteristics of the respondents are presented in Table 1. 
Budihastuti et al./ Improved Understanding of Intra Uterine Device

Table 1. Characteristics of Family Planning Acceptors Respondents

\begin{tabular}{lcc}
\hline \multicolumn{1}{c}{ Variable } & $\mathbf{N}$ & \% \\
\hline Types of contraception & & \\
Implants & 38 & 63.3 \\
IUD & 22 & 36.7 \\
Age (years) & & \\
$>36$ & 24 & 40 \\
$\leq 36$ & 36 & 60 \\
Body Mass Index (BMI) $\left(\mathbf{k g} / \mathbf{m}^{\mathbf{2}}\right)$ & & 65 \\
$<25$ & 39 & 35 \\
$\geq 25$ & 21 & 10 \\
Education & & 35 \\
Elementary school & 6 & 46.7 \\
Junior High & 21 & 8.3 \\
High school & 28 & 61.7 \\
College & 5 & 38.3 \\
Number of children alive & & \\
$\leq 2$ & 37 & 6.7 \\
$>2$ & 23 & 70 \\
Occupation & & 1.6 \\
Teacher & 4 & 21.7 \\
Housewife & 42 & \\
College student & 1 & \\
Entrepreneur & 13 & \\
\hline
\end{tabular}

\section{Bivariate analysis}

Furthermore, a bivariate analysis was carried out using Chi-square to determine whether the above characteristic variables had a significant effect on the group that was given counseling or not. The complete bivariate analysis results are presented in Table 2.

Table 2. Homogenity, Demography, and Clinical Factors

\begin{tabular}{|c|c|c|c|c|c|c|c|c|}
\hline \multirow{3}{*}{ Independent Variable } & \multicolumn{4}{|c|}{ Group } & \multirow{2}{*}{\multicolumn{2}{|c|}{ Total }} & \multirow{3}{*}{$\mathbf{p}$} & \multirow{3}{*}{ OR } \\
\hline & \multicolumn{2}{|c|}{$\begin{array}{c}\text { With } \\
\text { Counseling }\end{array}$} & \multicolumn{2}{|c|}{ Control } & & & & \\
\hline & $\mathbf{n}$ & $\%$ & $\mathbf{n}$ & $\%$ & $\mathbf{n}$ & \% & & \\
\hline \multicolumn{9}{|l|}{ Types of contraception } \\
\hline IUD & 12 & 40.0 & 10 & 33.3 & 22 & 100 & 0.583 & 1.406 \\
\hline Implants & 18 & 60.0 & 20 & 66.7 & 38 & 100 & & \\
\hline \multicolumn{9}{|l|}{ Age (years) } \\
\hline$>36$ & 18 & 60.0 & 12 & 40.0 & 30 & 100 & 0.001 & 11.000 \\
\hline$\leq 36$ & 12 & 40.0 & 18 & 60.0 & 30 & 100 & & \\
\hline \multicolumn{9}{|l|}{ BMI $\left(\mathrm{kg} / \mathrm{m}^{2}\right)$} \\
\hline$<25$ & 24 & 80.0 & 21 & 70.0 & 45 & 100 & 0.005 & 6.182 \\
\hline \multirow{2}{*}{\multicolumn{9}{|c|}{ Number of children alive }} \\
\hline & & & & & & & & \\
\hline$\leq 2$ & 16 & $53 \cdot 3$ & 19 & 63.3 & 35 & 100 & 0.009 & 5.250 \\
\hline $\begin{array}{l}>2 \\
\text { Occupation }\end{array}$ & 14 & 46.7 & 11 & 36.7 & 25 & 100 & & \\
\hline Working at home & 21 & 70.0 & 24 & 80.0 & 45 & 100 & 0.333 & 1.833 \\
\hline Working outside & 9 & 30.0 & 6 & 20.0 & 15 & 100 & & \\
\hline
\end{tabular}


Table 3. Results of Multiple Logistic Regression onCounseling Satisfaction, Convenience, and Service Satisfaction in Family Planning

\begin{tabular}{|c|c|c|c|c|c|c|}
\hline \multirow[b]{2}{*}{ Variable Dependent } & \multirow{2}{*}{$\begin{array}{c}\text { Very } \\
\text { Satisfied } \\
(\%)\end{array}$} & \multirow{2}{*}{$\begin{array}{c}\text { Not } \\
\text { Satisfied } \\
(\%)\end{array}$} & \multicolumn{2}{|c|}{$95 \%$ CI } & \multirow[b]{2}{*}{$\mathbf{O R}$} & \multirow[b]{2}{*}{$\mathbf{p}$} \\
\hline & & & $\begin{array}{l}\text { Lower } \\
\text { limit }\end{array}$ & $\begin{array}{l}\text { Upper } \\
\text { limit }\end{array}$ & & \\
\hline \multicolumn{7}{|c|}{$\begin{array}{l}\text { Family planning counseling } \\
\text { satisfaction }\end{array}$} \\
\hline $\begin{array}{l}\text { With counseling } \\
\text { Control }\end{array}$ & $\begin{array}{l}21(70.0) \\
16(53.3)\end{array}$ & $\begin{array}{l}9(30.0) \\
14(46.7)\end{array}$ & 1.097 & 2.310 & 1.592 & 0.014 \\
\hline \multicolumn{7}{|l|}{$\begin{array}{l}\text { Family insertion } \\
\text { convenience }\end{array}$} \\
\hline $\begin{array}{l}\text { With counseling } \\
\text { Control }\end{array}$ & $\begin{array}{l}22(73 \cdot 3) \\
21(70.0)\end{array}$ & $\begin{array}{l}8(26.7) \\
9(30.0)\end{array}$ & 0.976 & 2.090 & 1.428 & 0.066 \\
\hline \multicolumn{7}{|l|}{$\begin{array}{l}\text { Family planning service } \\
\text { satisfaction }\end{array}$} \\
\hline $\begin{array}{l}\text { With counseling } \\
\text { Control }\end{array}$ & $\begin{array}{l}21(70.0) \\
22(73.3)\end{array}$ & $\begin{array}{l}9(30.0) \\
8(26.7)\end{array}$ & 1.191 & 2.603 & 1.761 & 0.004 \\
\hline
\end{tabular}

\section{Multivariate analysis}

Table 3 showed that counseling, good family planning services and comfort of the insertion increased satisfaction.

\section{DISCUSSION}

The Family Planning Program is one of the Indonesian government's health programs that aims to reduce population growth while reducing maternal and infant mortality rates in Indonesia. In its implementation, the family planning program is a shared responsibility between the government, medical personnel and the community. Thus, this program needs to be continuously improved by prioritizing quality and sustainable service aspects and receiving positive support from the community. Improving the quality of family planning services aims to assist family planning acceptors in achieving optimal individual health, and to reduce fertility rates through increased use of contraceptives. The high failure rate and the number of unwanted pregnancies due to hormonal contraceptive methods and barrier methods indicate that a long-acting contraceptive methods with simple compliance is needed (Speroff, 2020).
This study discusses the analysis of increasing understanding and satisfaction of family planning acceptors with family planning services. The research analysis was measured through the satisfaction level of family planning acceptors with counseling about contraceptives, the level of comfort in the insertion of contraceptives, and the level of satisfaction with family planning services by doctors or medical personnel. A total of 60 respondents came from the women divided into 2 groups. Group A consisted of 30 respondents who had used the IUD and implant as control group, and group B consisted of 30 respondents who would be given counseling and the insertion of IUD and implant.

Of the 60 respondents studied, it was found that the majority level of satisfaction with extension services was "very satisfied". This shows that there is an increase in understanding and satisfaction of family planning acceptors with the quality of doctors or medical personnel in providing information related to contraceptives. In this outreach, medical personnel provided complete information about the types and options of contraception available, as well as their respective strengths and weak- 
nesses. In addition, counseling also aims to help family planning acceptors decide on the choice of contraceptive method that best suits their individual and family special circumstances. This is in line with previous study that a better understanding of high quality contraception is needed to increase effective, efficient and rational contraceptive users (Amran et al., 2019).

The comfort level of family planning acceptors in the insertion of contraceptives by medical personnel has a "very satisfied" rate of $71.1 \%$. The results of this study indicate that doctors or medical personnel have a good ability to provide a comfortable effect on the insertion of contraceptives. This of course will affect the quality of family planning services.

Furthermore, the satisfaction level of family planning acceptors with family planning services provided by medical personnel at Solo Peduli Clinic has a "very satisfied" score of $71.7 \%$. This shows that the overall family planning services provided are of good quality so as to give satisfaction to family planning acceptors.

The data were then analyzed again to look for the significance value (p) and the odds ratio (OR), to find out whether there was a relationship between groups A and B with the level of satisfaction with counseling, the effect of convenient insertion, and satisfaction with family planning services at the Solo Peduli Clinic.

The results of the analysis showed $\mathrm{p}$ value $<0.05$ on the satisfaction level variable of family planning counseling and services. This shows that there is a significant relationship between the two groups of family planning acceptors with the level of satisfaction with family planning counseling and services at the Solo Peduli Clinic. Providing counseling prior to the insertion of contraceptives can increase the satisfac- tion of family planning acceptors with family planning services.

The OR value $>1$ on the level of satisfaction with counseling and services stated that group B who was provided with counseling had a greater level of satisfaction than group A who was control group. This shows that the provision of information about contraceptives to family planning acceptors has a very important role in increasing satisfaction and quality of family planning services.

Complete information about family planning contraceptives should be given to family planning acceptors. This is in line with the Indonesian Ministry of Health (2015) which states that family planning acceptors must be provided with complete information about the contra indications for the use of various types of contraceptives to be chosen and a good understanding by medical personnel regarding appropriate family planning services. The obligation of health workers in family planning clinics to provide information to family planning acceptors is also a mandate of the law. If the clinic staff does not do it well, then it can be considered as a violation of the mandate of the law as stipulated in Law No. 36 of 2009 concerning Health, especially article 56 , that everyone has the right to accept or reject part or all of the relief measures that will be given to him or her after receiving and understanding the complete information regarding the action (Kementerian Kesehatan RI, 2015; WHO, 2020).

Most of the respondents chose to use the implant contraceptive method (63.3\%) and intrauterine contraception or IUD (36.7\%). Long-acting reversible contraception (LARC) such as implants and IUDs are one of the most effective birth control options for preventing pregnancy. Family Planning methods with implants and IUDs 
are the main choice of most family planning acceptors because they use simple, safe, cost-effective, and long-term methods (Wu and Pickle, 2014; Wathoni et al., 2018).

In terms of service quality, the indicator is not only determined by the medical personnel serving it, but is more determined by the party being served (acceptors), because they are the ones who enjoy the service so that they can measure the quality of service based on their expectations in meeting their satisfaction. The quality of family planning services includes several aspects such as Safe service, Privacy and confidentiality, Dignity, comfort and expression of opinion, and Continuity of care (Bhatia et al., 2011; Women, Care and Smith, 2015).

Safe service is the ability of health workers to provide health services safely. Family planning safe service includes the ability of medical personnel to examine patients, the ability to explain how to safely use oral contraceptives, implants and IUDs, the ability to help when there is a disturbance, the ability to listen to complaints well and the ability to provide a sense of security. Privacy and confidentiality is a health service that continues to provide protection for the privacy of patients and confidentiality, such as a close examination area, good and not disturbed by other people, complete examination equipment, other people cannot hear the conversation and guaranteed confidentiality. Continuity of care is explaining when the family planning acceptor visits to the next service, such as providing an explanation of the time of the next visit and if there is an emergency, danger signs and a place of referral if needed (Bhatia et al., 2011; Women et al., 2015).

In addition, the quality of family planning services can also be assessed from several aspects, namely the availability of contraceptive methods, the quality of information provided to clients (acceptors), interpersonal relationships between medical personnel and family planning acceptors, technical capabilities of medical personnel, advanced service mechanisms, and the accuracy of service delivery. Access to quality family planning services is an important element in the effort to achieve optimal reproductive health services. Everyone has the right to obtain information and access to various methods of contraception that are safe, effective and affordable (Kementerian Kesehatan RI, 2015; WHO, 2020). Limitations of this study are in the group who have used IUD and implant contraceptives as the control group the data is not known in detail the extent of counseling that has been given before contraceptive insertion.

\section{AUTHOR CONTRIBUTION}

Uki Retno Budihastuti, Abdurahman Laqif, Eriana Melinawati, Teguh Prakosa, Hermawan Udiyanto, Heru Priyanto, Darto, Affi Angelia Ratnasari, Asih Anggraeni, Dympna Prameilita Prisasanti, did counseling, collect the data, did data analysis, and wrote the paper.

\section{CONFLICT OF INTEREST}

The authors state that the research was conducted in the absence of a commercial or financial relationship which could be construed as a potential conflict of interest.

\section{FUNDING AND SPONSORSHIP}

This study was the output of research funded by Penerimaan Negara Bukan Pajak (PNBP) number453/UN27.21/PN/2020.

\section{ACKNOWLEDGEMENT}

The author would like to thank Dr. Moewardi Hospital, Universitas Sebelas Maret, and Solo Peduli Clinic. 


\section{REFERENCE}

Abdulreshid M, Dadi HB (2020). Assessment of family planning counseling provided for postpartum women and associated factors. Int J Reproductive Med. 1-5. https://doi.org/10.1155/$2020 / 2649340$.

Akintomide H (2019). Improving information on intrauterine contraception: Providing advice in primary care. British J General Prac. 69(679): 9899. doi: 10.3399/bjgp19X701237.

Amran Y, Nasir NM, Dachlia D, Yelda F, Utomo B, Ariawan I, Damayanti R (2019). Perceptions of contraception and patterns of switching contraceptive methods among family-planning acceptors in West Nusa Tenggara, Indonesia. J Preventive Med Public Health. 52(4): 258-264. doi: 10.3961/jpmph.18.198.

Bhatia P, Nangia S, Aggarwal S, Tewari C (2011). Implanon: Subdermal single rod contraceptive implant. Journal of Obstetrics and Gynecology of India, 61(4): 422-425. doi: 10.1007/s13224011-0066-z.

Cheung, M.-L. et al. (2018) 'Retained Intrauterine Device (IUD): Triple Case Report and Review of the Literature', Case Reports in Obstetrics and Gynecology, 2018, pp. 1-8. doi: 10.1155/2018/9362962.

Committee on Practice Bulletins-Gynecology, Long-Acting Reversible Contraception Work Group (2011). Longacting reversible contraception: Implants and intrauterine devices. Obstetrics \& Gynecology, 118(1): 184196. doi: 10.1097/AOG.obo13e318227 fo5e.

Esposito CP, LoGiudice J (2019). Beliefs and use of intrauterine devices (IUDs) among women's health care provid- ers. J Nurse Pract. 15(9): 682-687. doi: 10.1016/j.nurpra.2019.05.005.

Everret S (2008) Buku Saku Kontrasepsi dan Kesehatan Seksual Reproduktif. Jakarta: EGC.

Hsia JK, Creinin MD (2016). Intrauterine Contraception. Seminar in Reproductive Medicine, 34(3): 175-182. doi: 10.1055/s-0036-1571438.

İnal ZÖ, İnal HA, Küçükkendirci $\mathrm{H}$, Oruç AS, Günenç O (2017). The level of using family planning methods and factors that influence the preference of methods in the Konya-Meram area. J Turk Ger Gynecol Assoc. 18(2): 7276. doi: 10.4274/jtgga.2016.0180.

Kementerian Kesehatan RI (2015). Kesehatan dalam Kerangka Sustainable Development Goals (SDGs). Rakorpop Kementerian Kesehatan RI. Available at: http://www.pusat2.litbang.depkes.go.id/pusat2_v1/wpcontent/uploads/2015/12/SDGs-Ditjen-BGKIA.pdf.

Kohn JE, Hacker JG, Rousselle MA, Gold M (2012). Knowledge and likelihood to recommend intrauterine devices for adolescents among school-based health center providers. J Adolesc Health. 51(4): 319-324. doi: 10.1016/j.jadohealth.2011.12.024.

Kolawole OO, Sowemimo OO, Ojo OO, Fasubaa OB (2018). Contraceptive implants: A review and current perspective in southwest Nigeria. Trop $\mathrm{J}$ Obstet Gynaecol, 35(2): 108-112. doi: 10.4103/TJOG.TJOG.

Ohihoin GA, Bello B, Herbertson EC, Ezechi OC (2015). Use of modern contraceptive implants the: Lagos island maternity Hospital experience. Tropical journal of obstetrics and gynaecology. 32(2): 125-131.

Pleaner M, Morroni C, Smit J, LinceDeroche N, Chersich M, Mullick S, 
Budihastuti et al./ Improved Understanding of Intra Uterine Device

Pillay D, Makua M, Rees H (2017). Lessons learnt from the introduction of the contraceptive implant in South Africa. South African Med J. 107(11): 933-938. doi: 10.7196/SAMJ.2017.v107 i11.12805.

Prosad S, Mashamba-Thompson TP, Ojewole E (2018). Evidence of patients' challenges and barriers related to usage of Implanon $囚$ : Scoping review protocol. Systematic Reviews. 7(157): 1-6. doi: 10.1186/s13643-018-0827-1.

Rajuddin R, Fauzan F (2019). The association of acceptance family planning acceptor to contraceptive tools interest usage in the uterine (IUD). Indonesian J Obstetrics Gynecology. 7(1): 46. doi: 10.32771/inajog.v7i1.829.

Speroff L (2020). Clinical Gynecologic Endocrinology and Infertility. Nine Editi. Wolters Kluwer.

Wathoni N, Alfauziah TQ, Rantika N (2018). Evolution of contraceptive implants: A review. Int J Applied Pharm.
10(6): 16-22. doi: 10.22159/ijap.2018v10i6.28391.

Women J, Care H, Smith SA (2015). The Use of Intrauterine Devices (IUDs) in Adolescents and Nulliparous Women: A Systematic Review. Journal of Womens Health Care, 04(06). doi: 10.4172/2167-0420.1000277.

World Health Organization (2020). Family planning/Contraception Methods. Available at: https://www.who.int/news-room/fact-sheets/detail/familyplanning-contraception.

Wu JP, Pickle S (2014). Extended use of the intrauterine device: A literature review and recommendations for clinical practice. Contraception. Elsevier Inc., 89(6): 495-503. doi: 10.1016/j.contraception.2014.02.011. 